ОСОБЕННОСТИ БЕЛОРУССКОЙ ${ }^{1}$ ПСИХОЛОГИИ В 1920-1950 ГГ.: ИСТОРИКО-КУЛЬТУРНЫЕ ПРЕДПОСЫЛКИ. ЧАСТЬ 2. ПСИХОЛОГИЧЕСКИЕ ОСОБЕННОСТИ БОЕВОЙ ДЕЯТЕЛЬНОСТИ В ПАРТИЗАНСКИХ ОТРЯДАХ

\author{
(С2021 г. С.Л. Кандыбович*, Т.В. Разина**
}

*Академик РАО, доктор психологических наук, профессор, ведущий научный сотрудник,
ФГБОУ ВО «Рязанский государственный университет имени С.А. Есенина»;
390000, Рязань, ул. Свободы, д. 46; e-mail: s.kandybovich@sodru.com

**Доктор психологических наук, профессор РАО, главный аналитик, ФГБУ «Российская академия образования»; 119121, Россия, Москва, ул. Погодинская, д. 8; e-mail: razinat@mail.ru

DOI: $10.38098 /$ ipran.sep.2021.21.1.001

Поступила в редакцию 11 января 2021 г.

Аннотация. Продолжено рассмотрение ситуации, сложившейся в белорусской психологии в период Великой Отечественной войны, и роль этого этапа истории в ее дальнейшем развитии. Представлен малоизученный факт использования житейских психологических знаний в организации и ведении партизанской войны. Показано, что специфика партизанской войны с необходимостью требовала от бойцов и командиров применения психологических знаний и умений. При этом, несмотря на отсутствие документов, официально подтверждающих наличие лиц со специальной психологической подготовкой в боевых партизанских соединениях, данные задачи выполнялись достаточно эффективно. К числу подобного рода задач и специфики партизанской борьбы относятся: психологические аспекты организации и координации деятельности партизанских отрядов, особенности командования в них, необходимость учета этнонациональных особенностей как противника, так и членов партизанских отрядов, особенности взаимодействия и коммуникации между гражданскими и военными лицами внутри партизанских отрядов, психологическая подготовка бойцов (наряду с профессиональными навыками) партизанских отрядов (воспитание мужества, стойкости, готовности и т.д.). Также значительное место в боевых действиях партизан занимало осуществление психологической войны в тылу врага и параллельное проведение идеологической и воспитательной работы среди населения оккупированных территорий при необходимости эффективного функционирования в длительной экстремальной ситуации и в ситуации неопределенности, развитие устойчивости к ней. Важной задачей являлся психологический отбор, в первую очередь связанный с необходимостью определения потенциальных предателей и оценки возможностей использования помощи местного населения и др. Таким образом, в истории белорусской психологии в период Великой Отечественной войны сложилась уникальная ситуация широкого использования житейских психологических знаний и их спонтанный переход на уровень прикладных. Тем не менее, прямого развития этой отрасли психологической науки после Великой Отечественной войны в белорусской психологии не произошло.

Ключевые слова: белорусская психология, история психологии, историческая психология, история советской психологии, партизанская война в Белоруссии, Великая Отечественная война.

\footnotetext{
${ }^{1}$ В данной статье используются названия Белоруссия и БССР в соответствии с тем, как Республика Беларусь именовалась в рассматриваемый исторический промежуток времени - 1935-1950 гг.
} 
В период Великой Отечественной войны на оккупированной территории Белоруссии действовало значительное число партизанских отрядов. Партизанское сопротивление в Белоруссии было уникальным по своему масштабу и мощи освободительным движением, не имеющим аналогов в Новой и Новейшей истории. Партизанами контролировались значительные территории, на которых работали школы, типографии, больницы, было централизовано налажено сельское хозяйство. Даже в близлежащих областях - Брянской, Псковской, Ленинградской, на Украине - партизанское движение не имело такого размаха и успеха. Причин этому можно назвать несколько - и зверства гитлеровцев на территории Белоруссии, которые вызвали волну ненависти и возмущения, и особенности национального менталитета белорусов, и специфику ландшафта и природных условий, которые сочетали в себе непроходимые участки (леса, болота), находившиеся в непосредственной близости от населенных пунктов и коммуникаций, что позволяло эффективно скрываться и вести диверсионную работу. В итоге, уже в первые месяцы войны, партизанское сопротивление стало серьезной военной силой, действующей на территории оккупированной БССР, и впоследствии оказало неоценимую помощь регулярным частям Советской Армии в ходе операции «Багратион». Безусловно, такая система требовала продуманной, мощной организации, на основе профессиональных, в первую очередь военных, а также и психологических знаний. Тем не менее, на сегодняшний день одной из самых малоразработанных отраслей военной психологии является психология партизанской войны. Несмотря на героизацию партизанского движения в различных войнах (начиная с войны 1812 г., партизанской и подпольной работы в периоды различных революций в нашей стране и других странах, а также в период Великой Отечественной войны), подавляющий объем литературы по этому вопросу носит художественный или художественно-публицистический характер, а также 


\section{С.Л. Кандыбович, Т.В. Разина}

Особенности Белорусской психологии в 1920-1950 гг.: историко-культурные предпосылки.

Часть 2. Психологические особенности боевой деятельности в партизанских отрядах

характер мемуаров, которые, безусловно, имеют определенную историкопсихологическую ценность. Что касается научных исследований данного вопроса, то в первую очередь это, безусловно, исторические исследования. В рамках военной науки профессиональных публикаций по этому вопросу также крайне мало. Можно назвать довоенную работу М.А. Дробова (Дробов, 1931), послевоенные труды И.Г. Старинова (Старинов, 1949, 1980, 1989; Брайко, Старинов, 1983-1984), а также практикоориентированные труды В.Н. Андрианова (Андрианов, 1964, 1971, 1976, 1981, 1988, 1989), работу А.И. Цветкова (Цветков, 1973). При этом они, безусловно, имеют определенное психологическое содержание, однако, не делают его предметом исследований. Тем не менее, изначально партизанская борьба организовывалась в условиях тотальной нехватки не только оборудования, оружия, но и необходимых знаний и навыков. Со временем партизанские отряды стали получать существенную помощь с «большой земли» - технику, подготовленную специалистами, но все равно одной из специфичных черт организации и ведения партизанской войны в Белоруссии остается крайне высокие способности к самоорганизации, обобщению и распространению накопленных знаний и опыта, в том числе, - психологического. Важно отметить, что источниками получения и накопления психологического знания являются не только специально организованные исследования, но и жизненный (житейский опыт), особенно групповой (см. современные работы: Кольцова и др., 2016; Психологическое знание..., 2018; и др.).

Целью данной статьи является анализ того, какое место и статус имели психологические знания и психологическая подготовка в период Великой Отечественной войны на территории Белоруссии в партизанских отрядах. Основными задачами партизанской войны в 1941-1945 гг. можно назвать уничтожение живой силы противника, ликвидация лжепартизан, коллаборационистов, боевое содействие регулярным частям РККА, 


\section{С.Л. Кандьбович, Т.В. Разина}

Особенности Белорусской психологии в 1920-1950 гг.: историко-культурные предпосылки.

Часть 2. Психологические особенности боевой деятельности в партизанских отрядах

диверсионная деятельность, разведывательная деятельность и контрразведка, восстановление и сохранение советской власти на оккупированных территориях, политическая деятельность и большевистская пропаганда, а также мобилизация боеспособного населения. На сегодняшний день мы не обладаем подтвержденными научными данными, что в партизанском и подпольном движении на территории Белоруссии участвовали психологи или психотехники. При этом даже беглый анализ психологической составляющей боевой деятельности партизан показывает еe высокую сложность и многокомпонентность. Перечислим лишь некоторые из выделенных нами психологических аспектов изучения партизанской борьбы, проиллюстрировав примерами.

\section{1. Психологические аспекты организации и координацчии деятельности} партизанских отрядов. Специфика боевой деятельности партизанского отряда предполагала достижение высочайшего уровня дисциплины при условии сохранения известной самостоятельности, автономности. Это касалось всей вертикали руководства, начиная от вопросов подчинения отдельных бойцов командиру отряда и кончая руководством всем партизанским движением.

Как отмечают исследователи, изначально руководство партизанскими отрядами осуществлялось стихийно, под воздействием первых эмоциональнонравственных порывов как гражданского населения, так и военных, оказавшихся на оккупированной территории и оторванных от регулярных частей Красной Армии.

По воспоминаниям Н.Д. Украинца: «Партизанское движение развивалось стихийно. В нем были три главных составляющих: первая - это формирование отрядов отступающей властью. В таком случае это зачастую происходило довольно искусственно, но при этом не было хорошо спланированным, программным действием. Поэтому немецкими военными такие отряды легко 


\section{С.Л. Кандыбович, Т.В. Разина}

Особенности Белорусской психологии в 1920-1950 гг.: историко-культурные предпосылки.

Часть 2. Психологические особенности боевой деятельности в партизанских отрядах

вычислялись и быстро уничтожались. Вторая составляющая, более фундаментальная, - это то, что создавалось партийными органами. На местах оставались секретари обкомов, как правило, они возглавляли одну из бригад, которая в последующем обрастала людьми. И третья составляющая - это когда штабы фронтов в своей полосе создавали и засылали в тыл отряды особого назначения, которые собирали на месте окруженцев и местное население. Они же ставили в строй, принимали присягу, одевали по возможности в военную форму. Такие соединения уже трудно было назвать партизанскими» (Республика-партизанка, 2020, с. 279).

Однако очень скоро были изданы специализированные документы, регламентирующие данные процессы. Необходимость создания партизанских отрядов обозначена уже в Директиве от 29 июня 1941 г. «О мобилизации всех сил и средств на разгром фашистских захватчиков», где задачами партизанских и диверсионных групп указаны борьба с частями вражеской армии, создание невыносимых условий для врага и т.д., при чем, «для руководства всей этой деятельностью заблаговременно, под ответственность первых секретарей обкомов и райкомов создавать из лучших людей надежные подпольные ячейки и явочные квартиры...» (Всенародное..., 1967, с. 49). Таким образом, конкретных указаний, как должна быть организована работа партизанских отрядов по большому счету не было, и руководство данными отрядами поручалось людям идеологически выверенным, но не имевшим опыта такой работы и не знавшим ее специфики. Несколькими днями позже в Постановлении ЦК ВКП(б) «Об организации борьбы в тылу германских войск» от 18 июля 1941 г. были даны более конкретные указания. Руководителями партизанских и подпольных отрядов также предполагалось назначать партийных и комсомольских работников, а также беспартийных, «преданных советской власти» и знакомых с условиями региона. Также должны быть организованы «боевые дружины и 
диверсионные группы из числа участников Гражданской войны и из тех товарищей, которые уже проявили себя в истребительных батальонах, в отрядах народного ополчения, а также из работников НКВД, НКГБ и др.». При этом ЦК ВКП(б) обязал «ЦК компартий союзных республик, крайкомы, обкомы должны сообщать ЦК ВКП(б) по специальному адресу фамилии товарищей, выделенных для руководства партизанскими отрядами» (Работа..., 1982, с. 89).

Таким образом, уже в первые дни войны ЦК ВКП(б) обозначил наличие централизованного руководства партизанскими отрядами. Однако конкретных указаний о том, какую деятельность партия и правительство ожидают от партизанских отрядов, не было сделано. Также нет никаких указаний относительно методики организации партизанской и подпольной борьбы. При том, что к 18 июля значительная часть БССР уже была оккупирована, и данные директивы просто не могли быть получены и реализованы. К 26 июля 1941 г. пал один из последних крупнейших городов Белоруссии - Могилев перешел под власть гитлеровцев, а 28 июля 1941 г. и вся территория БССР оказалась в оккупации. По мнению ряда авторитетных исследователей (Коваленя и др., 2004), в развитии белорусского партизанского движения можно выделить несколько этапов. При этом этап массового развития партизанского движения начинается с ноября 1942 г. когда уже была отлажена система связи, состоялась организация боевой деятельности, создана инфраструктура и т.д. Незадолго до этого (5 сентября 1942 г.) опубликован Приказ Народного комиссара обороны Союза ССР «О задачах партизанского движения», подписанный И.В. Сталиным (Приказ НКО СССР..., 1997). И именно с этого момента можно говорить о реальной руководящей роли ЦК ВКП (б) и Центрального штаба партизанского движения в организации партизанского сопротивления. В частности, в партизанских соединениях устанавливалась строгая централизация руководства разведывательной работой и вопросами контрразведки (Доморад, 1995). 
Оперативно-чекистские группы при партизанских формированиях стали создаваться с января 1942 г. (Органы..., 2003). Важную роль в организации и проведении контрразведывательной работы в тылу противника сыграли спецгруппы и спецотряды органов государственной безопасности, в состав которых входили чекисты, обладавшие необходимыми знаниями и опытом (Шиманская, 2016). Главной целью этого обеспечения было ограждение партизан от подрывной деятельности спецслужб противника и враждебных элементов (Попов, 2003). Чекисты выявляли двойников, засланных немцами к партизанам, проверяли вновь зачисленных в отряд бойцов на специальных заданиях, осуществляли захват сотрудников специальных служб противника, выявление их агентов и пособников. Как правило, в стихийно создававшихся партизанских отрядах вербовка и отбор бойцов происходил интуитивно, на основе прежнего опыта общения, т.е. с опорой на житейскую психологию. Как вспоминает участница партизанского отряда H.М. Буланова: «Когда началась война, в деревне стал стихийно формироваться партизанский отряд. Это было так: можно тебе доверять или нельзя. И вот сложился в Клястицах такой вот круг проверенных людей» (Республика-партизанка, 2020, с. 281). Однако, как отмечает А.Ю. Попов, не всегда действия сотрудников НКВД в партизанских отрядах встречали поддержку, иногда командиры вступали в открытое противостояние с членами НКВД, что, вероятно, было обусловлено определенным недоверием, страхом по отношению к данным структурам, оставшимся еще с довоенных времен, и чувством самостоятельности, свободы, которую давало положение партизана. Это в итоге приводило к недопустимым действиям и моральному разложению среди командования партизанских отрядов - к самогонокурению, открытым столкновениям между партизанскими отрядами, краже имущества и т.д. (Попов, 2003). Данные примеры, хотя и не являлись широко распространенными среди партизанских соединений, тем не 


\section{С.Л. Кандьбович, Т.В. Разина}

Особенности Белорусской психологии в 1920-1950 гг.: историко-культурные предпосылки.

Часть 2. Психологические особенности боевой деятельности в партизанских отрядах

менее, ставили проблему психологического отбора и повышения психологической устойчивости командного состава партизан.

2. Учет этнонациональных особенностей как противника, так и членов партизанских отрядов. По данным исторических исследований, в партизанском движении на территории БССР принимали участие интернационалисты - граждане европейских государств: 2500 поляков (Толстой, 1966, с. 16.), чехи, словаки, болгары, сербы, венгры, французы, немцы и австрийцы, несколько хорватов и македонцев (Под одним знаменем, 1963, с. 5.), с которыми необходимо было выстраивать эффективное взаимодействие, определять насколько можно доверять тому или иному человеку, зачастую даже не зная языка. Рассказывает участница партизанского движения Н.M. Данилкович: «Поскольку соединение № 9903 было организовано Главным разведуправлением, у нашего отряда были очень широкие связи. Все ребята ходили на задания даже в Польшу. Когда мы были уже в отряде, к нам из Кракова приезжала связная. Она знала только польский язык, русского не знала, но каким-то образом ей сделали документы, что она едет к тете в Коречин, а оттуда ее доставили к нам» (Республика-партизанка, 2020, с. 256).

В партизанских отрядах (да и в других регулярных воинских соединениях, выполнявших боевые задачи) межнациональные различия имели тенденцию стираться, уступая место ценностям боевого братства, цели добиться победы. Этот феномен отмечают многие исследователи, и особенно ярко он проявлялся в партизанских отрядах. Вспоминает участница партизанского движения Т.С. Лаврова: «Назначили меня командиром группы, я набрала в нее таких же молодых ребят, как и я. В ней были эстонец, один белорус - Андрей Лапшов, один русский. Потом появился еще парень из Сибири - бежал из немецкого плена, пришел в бригаду» (Республика-партизанка, 2020, с. 295). 


\section{С.Л. Кандьбович, Т.В. Разина}

Особенности Белорусской психологии в 1920-1950 гг.: историко-культурные предпосылки.

Часть 2. Психологические особенности боевой деятельности в партизанских отрядах

Анализ менталитета, особенностей логики и мышления противника позволял эффективно выстраивать разведывательную и диверсионную работу. Безусловно, никаких исследований национального характера немцев в те годы на оккупированной территории Белоруссии (да и нигде в СССР) не проводилось, и все возможные выводы делались на уровне житейской психологии, в ходе непосредственных наблюдений, простейших эмпирических обобщений. Рассказывает участница партизанского движения Н.М. Данилкович: «Тогда, в 1942 году, мы получили задание: нужно срочно передать на такой-то адрес пулемет, несколько ящиков патронов, винтовки. И как провезти? ...Родители наши так подумали: кого не будут проверять? Самое высокое начальство. Значит, нужен начальник полицейского участка, но он же сам спокойно кого угодно расстреливал, как тут задание выполнять? ...Тут нам помог этот полицейский из деревни Борки. И он в течение какого-то времени уговаривал начальников приехать к нам в гости. Говорил, там хуторок, хорошие люди живут, у них пасека, угощение, и не болтливые, никто не узнает, что вы там пировали. Полицейские приехали. Пили, ели. Мы им на стол накрывали. Самогон тогда у нас был хороший, ржаной и чистый, как спирт, хорошей очистки, градусов 90, наверное. Когда увидели, что они до кондиции уже дошли, папа дал одним взглядом брату понять, что пора готовить телегу. Брат вышел, потом папа, за ним я. А сестра с мамой оставались им подавать дальше. Мы завезли телегу в сарай, прикрыли дверь — и давай укладывать сначала ящики с патронами, на них — пулемет, винтовки и сверху много сена. ...Когда все было подготовлено, и телега с красивым конем в упряжи стояла у порога, проводили мы “гостей”, помогли им взобраться на телегу, на солому, и наш полицейский их повез. Проезжают посты, а часовые им только честь отдают. Так и доставили оружие по адресу сами начальники полицейского участка» (Республика-партизанка, 2020, с. 250-251). 


\section{С.Л. Кандьбович, Т.В. Разина}

Особенности Белорусской психологии в 1920-1950 гг.: историко-культурные предпосылки.

Часть 2. Психологические особенности боевой деятельности в партизанских отрядах

3. Взаимодействие, коммуникации внутри партизанских отрядов бывших гражданских и военных лии также было серьезной психологической задачей в связи с привнесением ими собственных правил, стилей, ценностей, специфики боевой работы. Разница в подходах к организации партизанской работы наглядно продемонстрирована в работе А.В. Меркулова (Меркулов, 2018б), который анализирует опыт двух руководителей партизанского движения: полковника, партизана-диверсанта И.Г. Старинова (Меркулов, 2018a), который сам имел огромный опыт и активно участвовал в партизанской и диверсионной работе, еще с 1930-х гг. готовил партизанские кадры, написал ряд учебных пособий, в том числе совершенно секретных, и партийно-государственного белорусского деятеля, в годы войны руководителя Центрального штаба партизанского движения П.К. Пономаренко. В этом анализе отчетливо наблюдается разница в подходах к партизанской борьбе, ее целям и основным ценностям. При этом Пономаренко также имел опыт боевых действий в Первую мировую войну, но мышление функционера, по-видимому на период Великой Отечественной войны уже доминировало (Пономаренко, 1986).

Безусловно, очень сильными интуитивными психологами должны были быть командиры и комиссары партизанских отрядов, обладать широким спектром средств воздействия на бойцов-партизан. Специфика партизанского сопротивления предполагает достаточную степень автономности и самостоятельности каждого члена партизанского отряда, в результате создается довольно благоприятная почва для нарушения субординации и потери управляемости партизанских соединений. Эта гибкость изначально отсутствовала и у партийной номенклатуры, и у военного командования. В некоторых условиях такие гражданские лица мирных профессий, как учителя и врачи, в решении ряда вопросов могли быть более эффективны. 


\section{С.Л. Кандьбович, Т.В. Разина}

Особенности Белорусской психологии в 1920-1950 гг.: историко-культурные предпосылки.

Часть 2. Психологические особенности боевой деятельности в партизанских отрядах

Однако, в конечном итоге, партизанские отряды должны были осуществлять боевые действия, уничтожать живую силу и технику противника, к чему гражданских лиц, как правило, не готовили ни психологически, ни функционально. В отрядах же техническая подготовка очень часто опережала подготовку психологическую. Рассказывает участница партизанского движения Н.М. Данилкович: «В самом начале нашего пребывания в лагере меня поставили часовым. Быстро объяснили: если идет кто, нужно кричать “Стой, кто идет?!”, не останавливается - стреляй на поражение. Стрелять-то мы умели хорошо. Вот я стою на посту, уже два часа ночи, а когда кто-то по болоту идет, болото чавкает. Слышу - идет кто-то. Кричу: “Стой, кто идет?!”. Он и остановился, а я не знаю, что дальше делать. Если б он шел - понятно, стрелять надо. А что делать, если остановился, - не знаю. Мне никто не объяснял» (Республика-партизанка, 2020, c. 256). Но далеко не во всех партизанских отрядах сразу появлялись лица со специальной военной подготовкой. Такое положение пагубно отражалось не только на эффективности действий, но и на существовании самого партизанского отряда.

4. Приведенный выше пример демонстрирует еще одно важнейшее направление партизанской работы - психологическую подготовку бойц̧ов (наряду с профессиональныли навыками) партизанских отрядов (воспитание мужества, стойкости, готовности и т.д.). По воспоминаниям И.Г. Старинова, подготовка к партизанской войне в нашей стране не прекращалась с гражданской воны и осуществлялась по линии ОГПУ и ГРУ. В тридцатые годы работало три партизанские школы - в Харькове, Куперске и Киеве (Старинов, 1997), тем не менее, специалистов, обладающих всеми навыками ведения партизанской и диверсионной войны, было крайне недостаточно. Изначально эта функция ложилась целиком на плечи командиров и комиссаров партизанских отрядов, которые также далеко не всегда обладали необходимыми навыками. Безусловно, 


\section{С.Л. Кандьбович, Т.В. Разина}

Особенности Белорусской психологии в 1920-1950 гг.: историко-культурные предпосылки.

Часть 2. Психологические особенности боевой деятельности в партизанских отрядах

когда партизанское движение стало очевидной и необходимой СССР силой начала проводиться подготовка специалистов: «В тылу советских войск были созданы учебные центры, базы, спецшколы по подготовке кадров для подпольной и партизанской борьбы. Так, на Западном фронте в середине июля 1941 года был создан оперативно-учебный центр. Срок подготовки партизанских кадров здесь составлял от 3 до 5 дней, позднее - 10 дней. В Полесской области ${ }^{2}$, в районе города Мозыря летом 1941 г. находилась база по подготовке подпольщиков. С апреля 1942 г. возле г. Мурома Горьковской области начали работу специальные курсы подготовки кадров для партизанских формирований и организаторских групп по созданию партизанских отрядов (эти курсы получили название «Особый белорусский сбор»). Функционировали спецшколы по подготовке радистов, подрывников, разведчиков (за 1942 год в тыл врага было направлено 175 диверсионных групп общей численностью 2077 человек). В тыл противника засылались как отдельные патриоты и группы для ведения разведывательной, диверсионной, организаторской и агитационной работы, так и целые партизанские отряды. Например, в мае 1942 г. в тыл врага (на территорию оккупированной Белорусской ССР) были направлены 12 партизанских отрядов общей численностью около 600 человек» (Республикапартизанка, 2020, с. 129). Как вспоминает участница партизанского движения Т.С. Лаврова: «Нас направили в Москву, в ЦК ВЛКСМ, и распределили в спецшколу № 2, где готовили инструкторов-подрывников. Спустя три месяца обучения отправили в тыл врага» (Республика-партизанка, 2020, с. 294).

Однако таких специалистов в республике катастрофически не хватало. Прием подавляющего числа бойцов в партизанские отряды продолжался на основе знания неформальной биографии человека - его поступков, личной

\footnotetext{
2 Данная область существовала в период 1938-1954 гг.
} 


\section{С.Л. Кандьбович, Т.В. Разина}

Особенности Белорусской психологии в 1920-1950 гг.: историко-культурные предпосылки.

Часть 2. Психологические особенности боевой деятельности в партизанских отрядах

истории, его семьи, того, какое мнение, образ о том или ином человеке складывался в широком социальном окружении (селе, деревне и т.д.), т.е. на основе житейской психологии. Определяющими в партизанской борьбе на территории Белоруссии в период 1941-1944 гг. выступали не столько профессиональные боевые навыки, сколько личностные качества, моральнопсихологическая устойчивость, следование нравственным идеалам и волевые качества. Если рассматривать боевую деятельность партизан как частный случай трудовой деятельности, то крайне редко было, когда профессионально-важные навыки практически полностью заменялись профессионально важными личностными качествами.

5. Осуществление психологической войны в тылу врага, параллельно проведение идеологической и воспитательной работы среди населения оккупированных территорий также требовало психологических знаний и навыков. В отечественной литературе данный вопрос освещен довольно скудно. В силу ряда причин, в том числе идеологического характера, долгие годы априорно предполагалась негласная и полная поддержка партизан со стороны гражданского населения. Как отмечает зарубежный исследователь данного вопроса Д. Армстронг, с учетом сложившейся в первые месяцы войны ситуации, когда большая часть населения на оккупированной немцами территории еще твердо не примкнула ни к той, ни к другой стороне, задачами партизан было: 1) удержать людей от сотрудничества с противником и 2) привлечь на свою сторону занимавших нейтральную или выжидательную позицию. В этом отношении партизанская пропаганда, которая ввелась в намного более опасных условиях, а также вступала в конфронтацию с немецкой пропагандой, вынуждена была, оставаясь в рамках официальной государственной советской идеологии, быть более гибкой и находить новые пути и способы для обращения к сердцам своих соотечественников, т.е. по сути учитывать изменившуюся систему ценностных 


\section{С.Л. Кандьбович, Т.В. Разина}

Особенности Белорусской психологии в 1920-1950 гг.: историко-культурные предпосылки.

Часть 2. Психологические особенности боевой деятельности в партизанских отрядах

ориентаций народа, в частности «отказывалась от коммунистической, идеологической и классовой риторики и уделяла особое внимание патриотическим лозунгам и призывам к созданию Народного фронта - «...для партизанского движения была характерна политика “уступок”, когда в устной пропаганде делались заявления (иногда с официального разрешения, но чаще, несомненно, без него) о том, что советский режим представляет собой меньшее из двух зол; что нападение Германии требует забыть о внутренних разногласиях перед лицом более страшного внешнего врага; что правительство в Москве со временем исправит все ошибки». «Другой основной линией советской пропаганды являлось «разоблачение» целей и практических действий немцев. Сначала основной упор делался на колониальных замыслах нацистов; позже, когда население на личном опыте смогло убедиться, как на самом деле ведут себя немцы, партизаны получили возможность использовать в своей пропаганде массу примеров жестокого обращения и зверств фашистов» (Армстронг, 2007).

По воспоминаниям Н.Д. Украинца пропагандистская работа внутри отрядов, в особенности с новыми членами велась довольно системно: «Занятия вели более опытные партизаны, которые приводили примеры из своей, пока еще небогатой партизанской практики. Рассказывали о жизни крестьян в деревнях, о наборе девочек 14-16 лет и вывозе их в Германию на принудительные работы, о повальном угоне скота, сборе продовольствия для немецких гарнизонов. Зачитывали сводки от Совинформбюро» (Республика-партизанка, 2020, с. 364). Этот пример демонстрирует, что психологические знания, изначально существовавшие в статусе индивидуальных, житейских, в процессе развития партизанского движения стали обобщаться и приобретать тенденцию к переходу на следующий уровень - прикладных.

Большую эффективность при проведении работы с населением имело распространение листовок. Изначально они изготавливались вручную, но 


\section{С.Л. Кандыбович, Т.В. Разина}

Особенности Белорусской психологии в 1920-1950 гг.: историко-культурные предпосылки.

Часть 2. Психологические особенности боевой деятельности в партизанских отрядах

позднее в «партизанских краях» были налажены небольшие типографии. Содержанием таких листовок являлась, как правило, информация об успешной деятельности партизанских отрядов, об успехах Красной Армии на фронтах, о знаменательных праздничных датах, отражающих героическую историю СССР и БССР (Первое мая, годовщина создания республики и т.д.), рассказы о зверствах фашистов, призывы оказывать содействие партизанам и вступать в партизанские отряды (см. рис. 1).

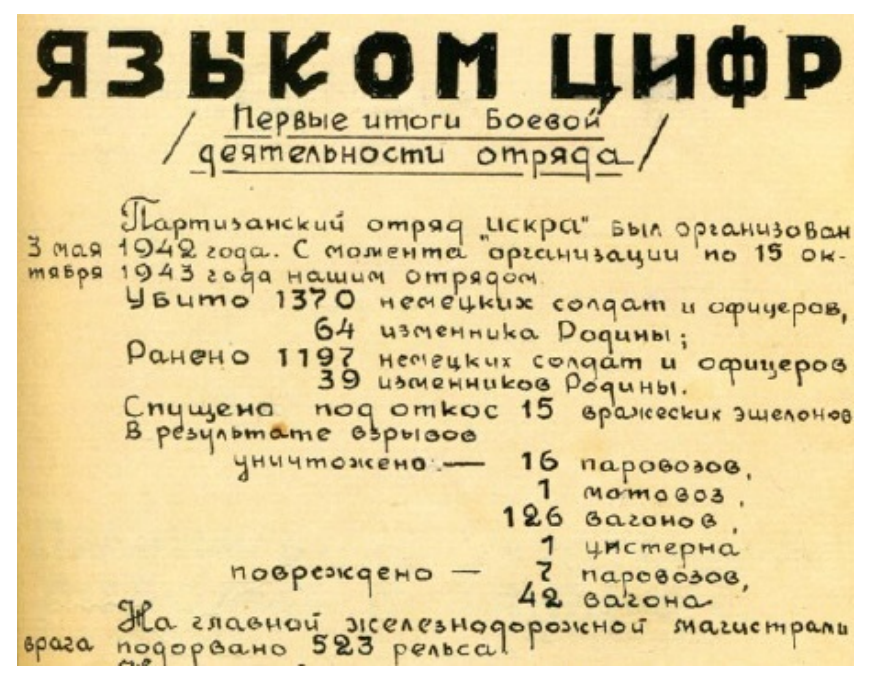

Результаты боевой деятельности партизанского отряда «Искра» (фрагмент)

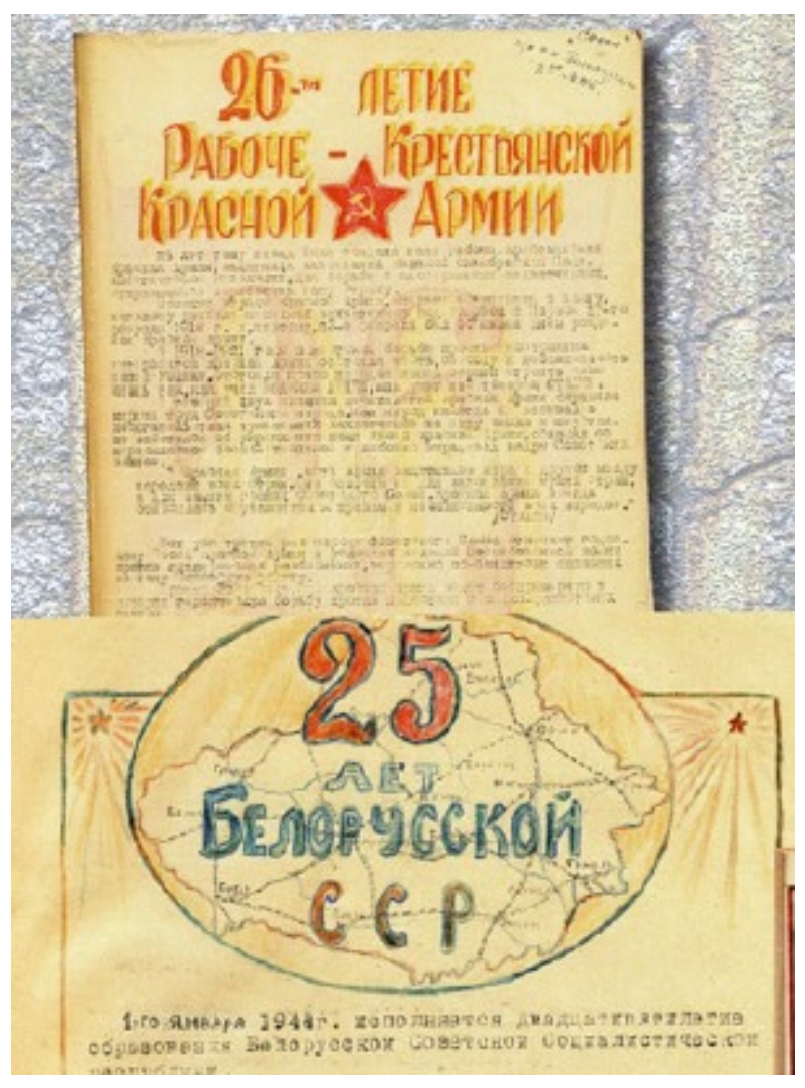

Праздничные открытки в партизанских журналах (фрагменты)

Рис. 1. Фрагменты из партизанских листовок и открыток, подготовленных партизанами к праздникам (Партизанский альманах, 2009)

Большим плюсом партизанской пропаганды было то, что партизаны говорили на одном языке с населением, многих знали лично, при необходимости 


\section{С.Л. Кандьбович, Т.В. Разина}

Особенности Белорусской психологии в 1920-1950 гг.: историко-культурные предпосылки.

Часть 2. Психологические особенности боевой деятельности в партизанских отрядах

помогали семьям или наоборот осуществляли операции возмездия, расстреливая тех, кто переметнулся на сторону врага. Как отмечает Армстронг, хотя это и весьма спорно, присутствие фашистов на территории Белоруссии давало возможность тем, кто решил сражаться против немцев, воплотить свою ненависть, чувство долга или мести в реальные действия - «...само их существование помогало сделать выбор и направить свои действия в нужное русло тем, кто принял решение, что являлось намного более важным, чем особые пропагандистские приемы, средства и тематика, используемые партизанами» (Армстронг, 2007). С последним утверждением автора можно согласиться лишь отчасти. Люди уходили не только в партизанские отряды, многие примкнули к лжепартизанам, коллаборационистам и т.д. Поэтому выбор именно партизанского движения был вполне осознанным, и, наверно, не всегда самым «рациональным» с точки зрения психологии самосохранения. Тем не менее, люди уходили в партизанские отряды на протяжении всей войны и вели их туда, в первую очередь, высшие чувства и ценности - патриотизм, любовь к своей Родине, к своему народу, чувство справедливости.

Отдельного внимания заслуживает опыт пропагандистской работы наших партизан с коллаборационистами и лжепартизанами. Безусловно, в большинстве случаев их уничтожали как предателей, однако, в ряде случаев одержать моральную победу было намного важнее, пусть это и было связано с большими трудностями. Вспоминает участница партизанского движения Т.С. Лаврова: «Моими усилиями целый полк власовцев перешел в партизаны. Это был полк предателей, прошедших военную школу в Берлине и направленных обратно выполнять задания в партизанском крае. Ребятам сказала не говорить комбригу, а сама пошла в деревню, от которой недалеко располагался гарнизон власовцев. Они приходили туда по субботам и воскресеньям - в баню и на танцы. Нашла в деревне свою ровесницу, девочку Катю, к которой, мне сообщили, ходил 
власовец. Пришла к ним в дом с автоматом и говорю: “Я партизанка, но если вы меня предадите, то партизаны за меня отомстят - вас расстреляют и дом разрушат”. И мы договорились с ней, что я представлюсь ее двоюродной сестрой. Оставила в доме пистолет, автомат - в сенях. Надела нарядное платье, идем вместе на танцы. Я танцую, знакомлюсь с ребятами. Провожать нас пошел командир власовцев, по званию как у нас старший сержант, из Харькова парень. Он провожает Катю домой, и я иду с ними. Два раза приходила на танцы, на третий думаю: “Нет, не могу уже больше танцевать”. Пришли мы с танцев, я и говорю: “Я партизанка. У меня в сенях автомат. Оставляй свой автомат, полезем на чердак разговаривать”. Он оставил оружие, я продолжаю: “Сколько вы будете воевать против нас? Вы разбили наши землянки, наши котлы разбили, наш комиссар подорвался на вашей мине. Харьковскую область уже освобождают от немецких оккупантов, а что вы думаете делать дальше? Вы же стали военными преступниками, пойдете под трибунал. Переходите на нашу сторону, и тогда, я обещаю, после войны вас не расстреляют”. Отдала ему сводки информбюро о победах советских войск, дала ему на раздумье и на агитацию своих солдат неделю: “В воскресенье я вас жду. Сколько, ты думаешь, перейдут?” Он сказал, что их в отряде 50 человек, но перейдут, может быть, меньше. ... В итоге 29 человек пришли. Комбригу рассказала, что власовцы переходят к нам в отряд, только перед тем как пойти в деревню. Все делала без спросу, все на свою совесть рассчитывала. Ну, а комбригу делать нечего, только помогать мне» (Республикапартизанка, 2020, с. 296).

Приведенный пример - яркая иллюстрация того, что помимо идеологических мотивов и ценностных аспектов, в партизанской борьбе большую роль играл и учет особенностей национального менталитета (о чем уже говорилось выше). Это подтверждает, в первую очередь, возможность использовать идею славянского единства для объединения не только партизан и 


\section{С.Л. Кандьбович, Т.В. Разина}

Особенности Белорусской психологии в 1920-1950 гг.: историко-культурные предпосылки.

Часть 2. Психологические особенности боевой деятельности в партизанских отрядах

сочувствующего населения, но и коллаборационистов, и явных предателей. Безусловно, в то время это осуществлялось стихийно, но сам факт (и не единственный) позволяет предположить значительный потенциал данного направления в партизанской и политической борьбе сегодняшнего дня. Объединяющий этнонациональный потенциал славянских народов, однако, как показывает пример, может быть раскрыт лишь при особых условиях - наличия внешней угрозы, неоднозначности ситуации и более глубоких, смысложизненных сторон, объединяющих народы (хозяйствования на своей земле, почитания предков, продолжения рода и т.д.).

Приведенный выше пример является также свидетельством специфиики командования в партизанских отрядах, которые, с одной стороны, являясь вооруженными, боевыми соединениями, требовали военной структуры и стиля управления, но при этом важнейшим условием их эффективности являлась их гибкая адаптация к партизанским условиям. Только те командиры партизанских соединений могли быть успешны в реализации своих задач и, в итоге, сохранить личный состав, которым удалось адаптировать свой стиль руководства к текущим условиям и задачам.

6. Необходимость эффективного функичиоирования в длительной экстремальной ситуац̧ии $и$ в ситуацуии неопределенности $u$ развитие устойчивости к ней. Партизанская, а еще больше подпольная деятельность, требовала от ее участников не только идеологической и морально-нравственной, но и психологической устойчивости. Партизаны и особенно подпольщики прекрасно понимали, что в любой момент их могут вычислить, расстрелять, или могут пострадать их близкие, ни в чем не повинные люди. С одной стороны, люди находились в состоянии постоянного страха, а с другой - переживания чувства вины перед земляками, которых не смогли защитить, которые пострадали за пособничество партизанам. Как вспоминает участница 


\section{С.Л. Кандьбович, Т.В. Разина}

Особенности Белорусской психологии в 1920-1950 гг.: историко-культурные предпосылки.

Часть 2. Психологические особенности боевой деятельности в партизанских отрядах

партизанского отряда Н.М. Данилкович: «У нас так было: столько людей погибало, сколько было поймано, и мы все знали, что никто из нас не останется живым, поэтому главным было выполнить задание. Дали задание - думаешь, как выполнить только его, а потом следующее дают - и тоже только его» (Республика-партизанка, 2020, с. 257).

Таким образом, большинство белорусского населения в оккупации, и, в первую очередь, партизаны и подпольщики, находились в крайне нетипичной, психологически дискомфортной ситуации - минимальной временной перспективы, вызванной прямой, непосредственной и постоянной угрозой жизни. На территории Белоруссии нацистами было создано 260 концентрационных лагерей смерти, их филиалов и отделений. Самым крупным являлся Тростянецкий лагерь смерти, в котором за годы войны было уничтожено 206,5 тыс. человек. В городах организовывались специальные зоны проживания евреев - гетто, которых, по разным данным, было создано от 111 до 299 в 277 населенных пунктах. За время оккупации БССР было проведено свыше 140 карательных экспедиций, в ходе которых немецкими карательными отрядами было расстреляно 13788 человек, уничтожено 628 населенных пунктов вместе с жителями, 5295 населенных пунктов с частью жителей. Немецкие оккупационные власти часто использовали детей в качестве доноров крови. Местное население привлекалось к расчистке заминированных участков, было «живым щитом» в боевых операциях против партизан и войск Красной Армии. Из Белоруссии было вывезено около 400 тысяч человек на принудительные работы в Германию; 186 тысяч белорусов погибло на таких работах (Коваленя и др., 2004).

Для нормального функционирования психики человеку важно чувствовать, что время его жизни имеет некое продолжение в будущем, т.е. иметь надежду на то, что его жизнь не закончится сегодня или завтра. Редукция 
временной перспективы типична для военных, находящихся в ситуации боевых действий (т.е. является частью профессиональной деятельности), но в ситуации оккупации Белоруссии это было характерно для всех слоев населения, вне зависимости от их сферы деятельности. При этом подобная ситуация была довольно продолжительной - немецкая оккупация Белоруссии длилась 3 года. Соответственно, каждый житель республики так или иначе пытался найти выход из сложившейся ситуации - кто-то пойти в партизанский отряд, кто-то сотрудничать с оккупационными властями. Формированию же психологической устойчивости и способности функционировать в подобной ситуации постоянной угрозы жизни, на наш взгляд, способствовало такое этнонациональное качество белорусов как памярко́ўнасиьь - слово в белорусском языке, обозначающее личностное качество, не имеющее аналогов в других языках (и в русском), приблизительно соответствующее понятиям покладистость, умеренность, уступчивость, терпеливость, способность приспосабливаться к сложным условиям, в том числе, за счет редукции собственных потребностей.

7. Психологический отбор, в первую очередь связанный с необходимостью определения потенциальных предателей и возможностью использования помощи местного населения. Как отмечает в своей статье Н.А. Шиманская (Шиманская, 2016), апеллируя к многочисленным документам, это была сложнейшая работа, требующая тщательного изучения каждого кандидата на вербовку, недопущения проникновения в ряды агентов и связных, провокаторов и коллаборационистов. Ведь достаточно одного провокатора или ненадежного человека, чтобы сдать целую группу связных. Спрогнозировать же, как будет себя вести тот или иной человек, попав в руки фашистов, весьма тяжело. В условиях оккупированной территории, боевых действий, разведывательной работы и т.д. поведение человека может резко меняться, существенно отклоняясь от его стандартов в мирной жизни, более напоминать 


\section{С.Л. Кандьбович, Т.В. Разина}

Особенности Белорусской психологии в 1920-1950 гг.: историко-культурные предпосылки.

Часть 2. Психологические особенности боевой деятельности в партизанских отрядах

девиантное. Как уже говорилось выше, известные самостоятельность, инициатива и активность были необходимы членам партизанских соединений. Так, уничтожение продовольственных запасов в отдельно взятой деревне (без приказа командира партизанского отряда) могло быть расценено как положительно (лишение продовольствия немцев), так и отрицательно (лишение продовольствия жителей деревни). И, как отмечает М. Бартушка, девиантное поведение человека в условиях партизанской войны могло легко попасть под определение диверсионной деятельности, в результате чего могли быть расстреляны не диверсанты и предатели (Бартушка, 2014).

Ситуация осложнялась также тем, что значительное число участников и подполья, и партизанского движения были молодыми людьми, а в ряде случаев - детьми и подростками, у которых еще не до конца сформировались представления о нормах социально приемлемого поведения, был крайне небольшой жизненный опыт, недостаточно сформированная способность к волевому самоконтролю, ослабленный инстинкт самосохранения, но при этом было горячее желание помочь своей стране, отомстить за погибших родных, что делало таких членов партизанских отрядов зачастую опасными для всего партизанского отряда и для мирных жителей. Как вспоминает Н.М. Буланова, участница партизанского отряда: «У нас, у молодежи, в оккупации вообще был такой настрой - готовы были и на танк броситься. Однажды возникла у нас такая задумка. Люба Гайдукова, девочка из Клястиц, работала поваром у немцев. И вот мы решили где-нибудь достать яд и всыпать в еду немцам, чтобы побольше их потравить. Но яд достать мы сами не могли. Пришлось обращаться в отряд, чтобы нам достали яд. Мы сказали Володе Войцеховичу, он, наверно, это кому-то передал. У нас вообще система такая была - для конспирации каждый знает только 2-3 человека, и все. И вот приходит к нам Володя, с огромными глазищами: «Отбой, девки, вы что, с ума сошли!..». Это я сейчас 


\section{С.Л. Кандьбович, Т.В. Разина}

Особенности Белорусской психологии в 1920-1950 гг.: историко-культурные предпосылки.

Часть 2. Психологические особенности боевой деятельности в партизанских отрядах

понимаю, что нельзя было такого делать - ведь, немцы после такой акции согнали бы всех и без разбору уничтожили... А тогда - молодые совсем были, не подумали об этом, просто в бой рвались» (Республика-партизанка, 2020, c. 282).

8. Психологические знания требовались и для того чтобы грамотно использовать особенности местности (т.е. знания по географической психологии) для достижения поставленных боевых задач, в том числе, для маскировки объектов, мест базирования, дезинформации противника и т.д. Безусловно, в лесу это сделать значительно проще, чем в условиях городской среды, однако, эта задача также требовала представлений об особенностях восприятия предметов человеком, в том числе, с воздуха. Здесь нужно отметить значительную роль имплицитных знаний (т.е. вновь - житейской психологии) местного населения, касающихся природных и географических условий. Белорусские леса и болота были естественной средой обитания для многих поколений крестьян, поэтому их использование с целью маскировки не представляло для местного населения большого труда, в то время как для всех остальных это составляло довольно сложную задачу.

\section{ЗАКЛЮЧЕНИЕ}

Таким образом, анализ особенностей военной деятельности в партизанских отрядах и формированиях показывает значительную роль именно психологической работы и психологических знаний для их успешного функционирования и выполнения боевых задач, но при этом практически полное отсутствие научных данных и результатов исследований в этом направлении. Боевые задачи решались партизанами на основании апеллирования к житейскому опыту, либо (в редких случаях) психолого-педагогическим знаниям в смежных областях, которые весьма ограниченно можно было применять в 


\section{С.Л. Кандьбович, Т.В. Разина}

Особенности Белорусской психологии в 1920-1950 гг.: историко-культурные предпосылки.

Часть 2. Психологические особенности боевой деятельности в партизанских отрядах

организации партизанского движения. Этот опыт, несмотря на принципиальные изменения в стратегии, тактике, способах ведения боевых действий, и сегодня не теряет своей актуальности.

Подводя итоги, можно отметить, что такая широкомасштабная партизанская работа, которая развернулась именно на территории Белоруссии, была обусловлена, помимо всех перечисленных выше факторов, еще и особенностями национального менталитета белорусов, которые в условиях интернациональности партизанских отрядов, все же составляли партизанское большинство. Помимо уже упомянутой памярко́ўнасцุи, для белорусской культуры характерен выраженный коллективизм, сильно выраженная дистанция власти (восприятие социальной иерархии как естественного и правильного положения вещей), достаточно выраженная маскулинность (приоритет достижения результата над удовольствием от процесса), а также выраженный прагматизм (готовность адаптировать мировосприятие к конкретным обстоятельствам) и высокий уровень сдержанности и самодисциплины (Hofstede, 2020), сильно выраженное избегание неопределенности (низкая склонность к риску, которая, однако, в ситуации партизанской войны и оккупации, уступили место памярко́ўнасu̧и и прагматизму). Безусловно, черты национального менталитета, как правило, не трансформируются напрямую в особенности личности каждого конкретного индивида. Тем не менее, данный психологический портрет белоруса, а соответственно и белорусского партизана, может послужить основой для дальнейшего формирования перечня профессионально важных качеств при подготовке военных специалистов подобного рода. Однако не стоит забывать и тот факт, что партизанская война явление в первую очередь коллективное, а потому имеющее системную природу. Многонациональность партизанских отрядов в определенной степени могла компенсировать те личностные качества, которых в ряде случаев могло 
недоставать белорусам. К сожалению, во времена Великой Отечественной войны подобные исследования не проводились. Опыт партизанской жизни и деятельности не был в свое время осмыслен в его психологических аспектах, а теперь сделать это чрезвычайно сложно. Однако, если бы это было сделано, то внесло бы значительный вклад в развитие военной психологии.

На сегодняшний день перед исторической психологией стоит задача работы с воспоминаниями участников партизанских отрядов, однако, в психологической науке методология такого рода исследований на текущий период еще недостаточно разработана по сравнению, например, с этнографией, которая широко использует самые разные источники, в том числе, данные «информантов», и не только о текущих событиях, но и о тех, которые происходили десятилетия назад, для установления так называемого этнографического факта (Измерение..., 2019; Сакральное..., 2004). Тем не менее, в психологических исследованиях использовать только историческую реконструкцию на основе воспоминаний недостаточно. В этом отношении весьма перспективными представляются сравнительные исследования, сопоставляющие исторические данные, полученные на основе анализа воспоминаний, с результатами современных исследований полевого характера. Современные реалии военных действий таковы, что в них, несмотря ни на что, по-прежнему остается место для партизанской войны, хотя и не в таком масштабе, как в Белоруссии в период ее оккупации. Отдельные аспекты могут быть крайне полезны в подготовке разведчиков и др.

Проведенный анализ позволяет сделать вывод, что в истории белорусской психологии в период Великой Отечественной войны в условиях борьбы партизанских отрядов сложилась уникальная ситуация достижения многообразных целей и решения задач на основе широкого использования не только знаний из смежных научных областей, но и психологических знаний. При 


\section{С.Л. Кандьбович, Т.В. Разина}

Особенности Белорусской психологии в 1920-1950 гг.: историко-культурные предпосылки.

Часть 2. Психологические особенности боевой деятельности в партизанских отрядах

этом используемые психологические знания носили в большинстве своем житейский характер. И если традиционно житейская психология - это индивидуальное использование психологического опыта в личных целях, то в партизанских краях это явление носило массовый характер, происходил активный обмен этим знанием, осуществлялись его обобщение и переход на новый прикладной уровень. Данная ситуация по своим механизмам в некотором роде напоминала формирование направления гуманистической психологии в США, которая изначально существовала как сугубо прикладное направление, на основе общности практических подходов и приемов работы. Однако в США в этих условиях профессиональные психологи, и впоследствии в гуманистической психологии сформировались собственные теории. Белорусская партизанская психология зарождалась из житейской психологии и можно сказать, что достигла прикладного уровня. Тем не менее, дальнейшего развития это направление не получило. На сегодняшний день не обнаружено документальных свидетельств о том, что бойцы партизанских отрядов стали профессиональными психологами, но подобный опыт мог передаваться опосредованно - детям, внукам, знакомым - в рассказах, воспоминаниях. В итоге тот опыт, возможно, не напрямую, но оказал определенное влияние на последующее становление белорусской психологии.

\section{СПИСОК ЛИТЕРАТУРЫ}

Андрианов В.Н. Организационная структура партизанских формирований в годы войны // Военно-исторический журнал. 1964. № 1. С. 38-46.

Андрианов В.Н. Борьба советских партизан в годы Великой Отечественной войны. М.: ВКШ КГБ при СМ СССР, 1971.

Андрианов B.H. Некоторые вопросы управления партизанскими формированиями // Военно-исторический журнал. 1976. № 5. С. 39-46. 
Андрианов B.Н. Советские партизаны и подпольщики в Великой Отечественной войне. М.: Знание, 1981.

Андрианов В.Н. Партизанская борьба в современных войнах и участие в ней органов государственной безопасности. М.: ВКШ КГБ при СМ СССР, 1988.

Андрианов B.Н. Основы партизанской борьбы: Пособие для практических работников. М.: ВКШ КГБ при СМ СССР, 1989.

Армстронг Д. Советские партизаны. Легенда и действительность. 1941-1944. М.: Центрполиграф, 2007. URL: http://propagandahistory.ru/books/DzhonArmstrong_Sovetskie-partizany--Legenda-i-deystvitelnost--1941-1944/～(дата обращения: 24.06.2020).

Бартушка М. Партызанская вайна ў Беларусі ў 1941-1944 гг. Смаленск: Інбелкульт, 2014.

Брайко П.Е., Старинов И.Г. Партизанская война. Основы организации партизанской войны, М.: Вымпел, 1983-1984.

Всенародное партизанское движение в Белоруссии в годы Великой Отечественной войны (июнь 1941 - июль 1944). Документы и материалы в трех томах. Минск.: Институт истории партии при ЦК КПБ - Филиал Института марксизмаленинизма при ЦК КПСС, 1967. Т. 1. С. 49-51.

Доморад К.И. Разведка и контрразведка в партизанском движении Белоруссии. 19411944 гг. Минск: Навука і тэхніка, 1995.

Дробов М.А. Малая война: партизанство и диверсии // Если завтра война? Малая война. Организация и тактика боевых действий малых подразделений. Хрестоматия. Минск: Харвест, 2003.

Измерение культурного многообразия. Языковая ситуация, переписи, полевая этностатистика. М.: ИЭА РАН, 2019.

Коваленя А.А., Лемешонок В.И., Краснова М.А., Новиков С.Е. Великая Отечественная война советского народа (в контексте Второй мировой войны). Минск: Изд. центр БГУ, 2004.

Кольцова В.А., Журавлев А.Л., Олейник Ю.Н. Изучение отечественной и мировой психологической мысли: результаты и перспективы исследований // История отечественной и мировой психологической мысли: судьбы ученых, динамика идей, содержание концепций. М.: Изд-во «Институт психологии РАН», 2016. С. 7-15.

Меркулов П.А. Илья Старинов. Иллюстрированная биография. Орел: Издательство Среднерусского института управления - филиала РАНХиГС, $2018 \mathrm{a}$.

Меркулов А.В. Полемика И.Г. Старинова и С.П. Пономаренко об истории партизанского движения в СССР 1941-1944 гг. // История: факты и символы. 2018б. № 3 (16). С.139-150. 
Органы государственной безопасности СССР в Великой Отечественной войне: Сб. док. Т. 3. Кн. 1. Крушение «Блицкрига». 1 января-30 июня 1942 г. / Федер. служба контрразведки РФ, Академия федер. службы контрразведки РФ / Рук. группы авт.сост. В.П. Ямпольский. М.: Русь, 2003.

Партизанский альманах. 1944-2009. Фотоальбом. Белорусский государственный музей истории Великой Отечественной войны. Минск: Изд-во «Белорусский Дом печати», 2009.

Пономаренко П.К. Всенародная борьба в тылу немецко-фашистских захватчиков 19411945 гг. М.: Наука, 1986.

Попов А.Ю. Партизаны и контрразведка в годы Великой Отечественной войны // Отечественная история. 2003. №3. С. 123-127.

Приказ НКО СССР от 5.09.1942 № 00189 // Приказы народного комиссара обороны СССР. 22 июня 1941 г.-1942 г. Т. 13(2-2). М.: Терра, 1997. С. 292-295.

Психологическое знание: современное состояние и перспективы развития / Отв. ред. А.Л. Журавлев, А.В. Юревич. М.: Изд-во «Институт психологии РАН», 2018.

Работа партийных организаций в период Великой Отечественной войны 1941-1945 годов. Документы и материалы в двух томах. Т. 1. М.: Правда, 1982. С. 8890.

Республика-партизанка. К 75-летию Победы в Великой Отечественной войне. Изд. 2-е, доп. и испр. / Отв. ред. С.Л. Кандыбович, В.В. Данилович, О.В. Солопова. М: Студия «Этника», 2020.

Сакральное в традиционной культуре: методология исследования, методы фиксации и обработки полевых, лабораторных, экспериментальных материалов // Этнологические исследования по шаманству и иным традиционным верованиям и практикам. Том 9. Часть 1 / Материалы Международного интердисциплинарного научно-практического семинара-конференции. Москва - Республика Алтай: 6-15 июля 2003 г. М.: Изд-во Института этнологии и антропологии РАН, 2004.

Старинов И.Г. Партизанское движение в Великой Отечественной войне. М.: ОГИЗ Госполитиздат, 1949.

Старинов И.Г. Диверсии и противодиверсионная защита. М.: Воениздат, 1980.

Старинов И.Г. Подготовка партизанских кадров. Научно-практическое пособие. М.: В/ч 33965, 1989.

Старинов И.Г. Записки диверсанта. М.: Альманах «Вымпел», 1997.

Толстой В.С. Братское содружество белорусского и польского народов. 1944-1964. Минск: Изд-во «Наука и техника», 1966. 
Цветков А.И. Основы организации и тактики партизанской борьбы. М.: Политиздат, 1973.

Шиманская Н.А. Контрразведывательная работа органов государственной безопасности в партизанских формированиях на оккупированной территории Беларуси (1941-1944) // Весн. БДУ. Сер. 3. Гісторыя. Эканоміка. Права. 2016. № 1. C. 19-25.

Hofstede G. Country Comparisons: Belarus / URL: https:/www. hofstede-insights. com/country-comparison/belarus/ (дата доступа: 05.06.2020).

\section{BIBLIOGRAFICHESKYJ SPISOK}

Andrianov V.N. Organizacionnaya struktura partizanskih formirovanij $\mathrm{v}$ gody vojny // Voenno-istoricheskij zhurnal. 1964. № 1. S. 38-46.

Andrianov V.N. Bor'ba sovetskih partizan v gody Velikoj Otechestvennoj vojny. M.: VKSH KGB pri SM SSSR, 1971.

Andrianov V.N. Nekotorye voprosy upravleniya partizanskimi formirovaniyami // Voennoistoricheskij zhurnal. 1976. № 5. S. 39-46.

Andrianov V.N. Sovetskie partizany i podpol'shchiki v Velikoj Otechestvennoj vojne. M.: Znanie, 1981.

Andrianov V.N. Partizanskaya bor'ba v sovremennyh vojnah i uchastie $\mathrm{v}$ nej organov gosudarstvennoj bezopasnosti. M.: VKSH KGB pri SM SSSR, 1988.

Andrianov V.N. Osnovy partizanskoj bor'by: Posobie dlya prakticheskih rabotnikov. M.: VKSH KGB pri SM SSSR, 1989.

Armstrong D. Sovetskie partizany. Legenda i dejstvitel'nost'. 1941-1944. M.: Centrpoligraf, 2007. URL: http://propagandahistory.ru/books/Dzhon-Armstrong_Sovetskiepartizany--Legenda-i-deystvitelnost--1941-1944/ (data obrashcheniya: 24.06.2020).

Bartushka M. Partyzanskaya vajna y̆ Belarusi y̆ 1941-1944 gg. Smalensk: Inbelkul't, 2014.

Brajko P.E., Starinov I.G. Partizanskaya vojna. Osnovy organizacii partizanskoj vojny, M.: Vympel, 1983-1984.

Vsenarodnoe partizanskoe dvizhenie v Belorussii v gody Velikoj Otechestvennoj vojny (iyun' 1941 - iyul' 1944). Dokumenty i materialy v trekh tomah. Minsk.: Institut istorii partii pri CK KPB - Filial Instituta marksizma-leninizma pri CK KPSS, 1967. T. 1. S. 4951.

Domorad K.I. Razvedka i kontrrazvedka v partizanskom dvizhenii Belorussii. 1941-1944 gg. Minsk: Navuka i tekhnika, 1995. 
Drobov M.A. Malaya vojna: partizanstvo i diversii // Esli zavtra vojna? Malaya vojna. Organizaciya i taktika boevyh dejstvij malyh podrazdelenij. Hrestomatiya. Minsk: Harvest, 2003.

Izmerenie kul'turnogo mnogoobraziya. YAzykovaya situaciya, perepisi, polevaya etnostatistika. M.: IEA RAN, 2019.

Kovalenya A.A., Lemeshonok V.I., Krasnova M.A., Novikov S.E. Velikaya Otechestvennaya vojna sovetskogo naroda (v kontekste Vtoroj mirovoj vojny). Minsk: Izd. centr BGU, 2004.

Kol'cova V.A., Zhuravlev A.L., Olejnik Yu.N. Izuchenie otechestvennoj i mirovoj psihologicheskoj mysli: rezul'taty i perspektivy issledovanij // Istoriya otechestvennoj i mirovoj psihologicheskoj mysli: sud'by uchenyh, dinamika idej, soderzhanie koncepcij.

Merkulov P.A. Il'ya Starinov. Illyustrirovannaya biografiya. Orel: Izdatel'stvo Srednerusskogo instituta upravleniya - filiala RANHiGS, 2018a.

Merkulov A.V. Polemika I.G. Starinova i S.P. Ponomarenko ob istorii partizanskogo dvizheniya v SSSR 1941-1944 gg. // Istoriya: fakty i simvoly. 2018b. №3 (16). S.139-150.

Organy gosudarstvennoj bezopasnosti SSSR v Velikoj Otechestvennoj vojne: Sb. dok. T. 3. Kn. 1. Krushenie «Blickriga». 1 yanvarya-30 iyunya 1942 g. // Feder. sluzhba kontrrazvedki RF, Akademiya feder. sluzhby kontrrazvedki RF / Ruk. gruppy avt.sost. V.P. Yampol'skij. M.: Rus', 2003.

Partizanskij al'manah. 1944-2009. Fotoal'bom. Belorusskij gosudarstvennyj muzej istorii Velikoj Otechestvennoj vojny. Minsk: Izd-vo «Belorusskij Dom pechati», 2009.

Ponomarenko P.K. Vsenarodnaya bor'ba v tylu nemecko-fashistskih zahvatchikov 19411945 gg. M.: Nauka, 1986.

Popov A.Yu. Partizany i kontrrazvedka v gody Velikoj Otechestvennoj vojny // Otechestvennaya istoriya. 2003. №3. S. 123-127.

Prikaz NKO SSSR ot 5.09.1942 № 00189 // Prikazy narodnogo komissara oborony SSSR. 22 iyunya 1941 g. -1942 g. T. 13 (2-2). M.: Terra, 1997. S. 292-295.

Psihologicheskoe znanie: sovremennoe sostoyanie i perspektivy razvitiya / Otv. red. A.L. Zhuravlev, A.V. Yurevich. M.: Izd-vo «Institut psihologii RAN», 2018.

Rabota partijnyh organizacij v period Velikoj Otechestvennoj vojny 1941-1945 godov. Dokumenty i materialy v dvuh tomah. T. 1. M.: Pravda, 1982. S. 88-90.

Respublika-partizanka. K 75-letiyu Pobedy v Velikoj Otechestvennoj vojne. Izd. 2-e, dop. i ispr. / Otv. red. S.L. Kandybovich, V.V. Danilovich, O.V. Solopova. M: Studiya «Etnika», 2020.

Sakral'noe v tradicionnoj kul'ture: metodologiya issledovaniya, metody fiksacii i obrabotki polevyh, laboratornyh, eksperimental'nyh materialov // Etnologicheskie 


\section{С.Л. Кандьбович, Т.В. Разина}

Особенности Белорусской психологии в 1920-1950 гг.: историко-культурные предпосылки.

Часть 2. Психологические особенности боевой деятельности в партизанских отрядах

issledovaniya po shamanstvu i inym tradicionnym verovaniyam i praktikam. Tom 9. CHast' 1 / Materialy Mezhdunarodnogo interdisciplinarnogo nauchnoprakticheskogo seminara-konferencii. Moskva - Respublika Altaj: 6-15 iyulya 2003 g. M.: Izd-vo Instituta etnologii i antropologii RAN, 2004.

Starinov I.G. Partizanskoe dvizhenie v Velikoj Otechestvennoj vojne. M.: OGIZ Gospolitizdat, 1949.

Starinov I.G. Diversii i protivodiversionnaya zashchita. M.: Voenizdat, 1980.

Starinov I.G. Podgotovka partizanskih kadrov. Nauchno-prakticheskoe posobie. M.: V/ch 33965, 1989.

Starinov I.G. Zapiski diversanta. M.: Al'manah «Vympel», 1997.

Tolstoj V.S. Bratskoe sodruzhestvo belorusskogo i pol'skogo narodov. 1944-1964. Minsk: Izd-vo «Nauka i tekhnika», 1966.

Cvetkov A.I. Osnovy organizacii i taktiki partizanskoj bor'by. M.: Politizdat, 1973.

Shimanskaya H.A. Kontrrazvedyvatel'naya rabota organov gosudarstvennoj bezopasnosti v partizanskih formirovaniyah na okkupirovannoj territorii Belarusi (1941-1944) // Vesn. BDU. Ser. 3. Gistoryya. Ekanomika. Prava. 2016. № 1. S. 19-25.

Hofstede G. Country Comparisons: Belarus / URL: https://www. hofstede-insights. com/country-comparison/belarus/ (data dostupa: 05.06.2020). 


\title{
FEATURES OF BELARUSIAN PSYCHOLOGY IN 1920-1950 y.: HISTORICAL AND CULTURAL PRECONDITIONS. PART 1. PSYCHOLOGICAL FEATURES OF COMBAT ACTIVITY IN PARTISAN DETACHMENTS
}

\author{
S.L. Kandybovich*, T.V. Razina**
}

*Academician of RAE, Sc.D. (psychology), professor, leading research officer, FSFEE HE «Yesenin Ryazan State University»; 18, Polonsky str., Ryazan, 390000; e-mail: s.kandybivich@sodru.com

**Sc.D. (psychology), associate professor, professor of RAE, chief analyst, FSFE «RussianAcademy of Education»; 8, Pogodinskaya str., Moscow, 119121; e-mail: razinat@mail.ru

Summary. The article continues to consider the situation in Belarusian psychology during the Great Patriotic War and the role of this stage in further development. The little-studied aspect is presented - the use of everyday psychological knowledge in the organization and conduct of guerrilla warfare. It is shown that the specifics of guerrilla warfare necessarily required fighters and commanders to apply psychological knowledge and skills. At the same time, despite the lack of documents officially confirming the presence of persons with special psychological training in combat guerrilla units, these tasks were performed quite effectively. Such tasks and specifics of guerrilla struggle include: psychological aspects of organization and coordination of guerrilla units, features of command in them, the need to take into account ethno-national characteristics of both the enemy and members of guerrilla units, features of interaction, communication within guerrilla units of civilians and military personnel; psychological training of fighters (along with professional skills) of guerrilla units (education of courage, perseverance, readiness, etc.). Also, a significant place in the guerrilla operations was occupied by the implementation of psychological warfare in the enemy's rear, parallel ideological and educational work among the population of the occupied territories, the need to function effectively in prolonged extreme situations and situations of uncertainty, development of resistance to it. An important task was psychological selection, primarily related to the need to identify potential traitors and the possibility of using the help of local people, etc. Thus, in the history of Belarusian psychology during the Great Patriotic War there was a unique situation of widespread use of psychological knowledge and their spontaneous transition to applied. Nevertheless, there was no direct development of this branch of psychological science in the Belarusian psychology after the Great Patriotic War.

Keywords: Belarusian psychology, history of Soviet psychology, guerrilla war in Belarus, Great Patriotic War. 